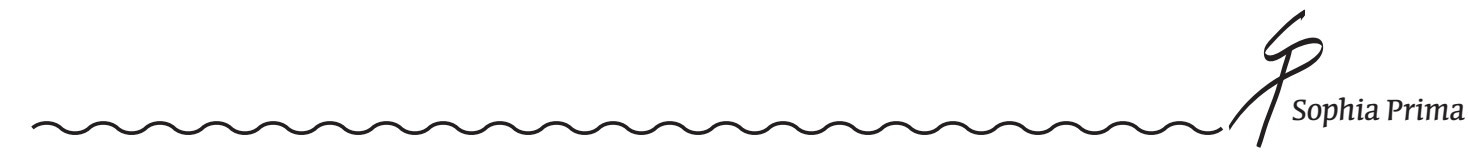

\title{
Philosophic sciences:
}

A friendship with wisdom

DOI: $10.34170 /$ ed.2019.2707-370X.2(1)-1

UDC 165.173:167:[316.65:24-285.52]

\author{
Elvira Gerasymova \\ Doctor of Philosophical Sciences, Professor, \\ National Pedagogical Dragomanov University, \\ Kyiv, Ukraine; \\ e-mail: sophiaprimauan@gmail.com \\ ORCID: 0000-0003-0046-8458
}

\section{ESSAY ABOUT SOCIAL MIND AS A PHENOMENON OF COLLECTIVE WISDOM}

\author{
- You must get well fast for there is much \\ that I can learn and you can teach me \\ everything. \\ How much did you suffer? \\ - «Plenty», the old man said.
}

Ernest Hemingway

Unprecedented forms of intellectual consumption of collective knowledge are being formed in today's social world. That is why the article deals with such problems of research methodology as a new format of communication methods within the scientific environment and the communication of intellectuals with the knowledge society, which consumes them. The phenomenon of collective wisdom is formed due to the principles and methods of system cognition, which is always creative and cannot be reduced only to its scientific form. Though it provides an opportunity for all members of the genus Homo sapiens to survive and arrange their lives. Collective wisdom is an integral indicator and a determinant of social progress and a mechanism of transformation. We constantly use other people's intelligence and this process is growing in scale, but the methods of communication between intellectual proposals do not have the appropriate contemporary forms, and the confirmation of objectivity of certain knowledge takes a lot of time.

The following criteria for collective wisdom were proposed: law as a known rational measure, knowledge as an experience of social reason, tradition as a unity of scientific experience, personal values and beliefs, and love as an ontological optimism of our existence. In some ways, they can help to form a unified platform for intellectual communication. The risks of widening an ignorance gap must be overcome by the holography of intellectual communication as a basis of collective wisdom. Furthermore, new methods for registration of "intellectual rays", which should take into account the results of modern quantum research methodology, molecular biology and other revolutionary opportunities in various fields of knowledge we suggested. 
Keywords: human, knowledge, methodology of scientific research, social intellect, collective wisdom, holography of intellectual communication.

\section{Why so?}

It is difficult to launch an extensive debate on Einstein's expression that God does not play dice. To empirically reach an understanding of the universal rules of the world, I begin to think: why don't I have a degree in physics? How then nowadays can I tackle the problems of ontology? Further, there is a problem with artificial intelligence, whereas I know well only the general courses in mathematics and biology. And besides, there are many times more questions than answers even with our "ordinary" intellect. There is a recognized scientific paradigm, in particular, we read T. Kuhn: "The paradigm is what unites members of the scientific community, and, vise versa, the scientific community consists of people who recognize the paradigm" ${ }^{1}$. I think further: scientific truth is acknowledged by whom? - By a circle of scientists. That is, first they mocked, did not recognize, they burned someone literally and in a figurative sense, and then changed their minds, and apologized. And so every time, but all this happens in the process of communication among those, whose right to the truth all other people agree with. The last, and perhaps not the final, example is the situation with Nobel laureate J.D. Watson, who laid the foundations of forming the most rapid modern scientific revolution in molecular biology. Based on experimental research, he noted: "There is a difference in tests between whites and blacks on the level of intelligence. I would say this difference is ... genetic", ${ }^{2}$ - I am impressed that the author himself was not pleased with such a result and would like to continue the research to refute the findings. As for "societal conclusions", he received them within a week, and then without comments.

I immediately recall a Marxist thesis that I had learned from a young age: the practice is the criterion of truth. Then I turn to U. Eco's opinion: "The world created by us indicates where the plot should go." ${ }^{3}$ Here is a situation of uncertainty: where is the practice and where is the truth? That is, all laws operate only in a certain coordinate system. I move from the concept of materialism to the opposite side of philosophizing: first, God gives Adam the right to call everything; later on, everyone understands each other, but they did not get along with God and could not build anything. What is more, a lot of people might confuse the Tower of Babel with the Tower of Pisa, change the first Qumran scrolls to ordinary sandals, but with that these people continue to be good specialists in their professions.

Moreover, the process of scientific knowledge formation leads to complications of the communication system, as a specific terminology of each professional activity field is formed, primarily due to the division of labor in the contemporary world. Next, we come across the meaning of a text, a context, a discourse, etc., i.e. with a problem of transmitting the meaning of new information and our viewpoint justification. In the contemporary research world, among the requirements for each scientific paper,

1 Kuhn, "The structure of scientific revolutions", 188.

2 Wikipedia. "James Watson."

3 Eco, "The Name of the Rose", 33. 
there is a norm that obliges an author to give his/her explanation for all key terms used in a text for its full understanding. Therefore, an actual task is to simplify requirements for scientific work. This is needed to solve a dilemma of complicating or contrary simplifying access to knowledge to attract more people and thus not to limit the amount of personal knowledge by profession choice at a young age. Contemporary world-renowned scientists associate the issue of solving civilization collisions with a change in the strategy of social intelligence. This position was fixed in the middle of the twentieth century in the Russell - Einstein Manifesto (Pugwash Conferences on Science and World Affairs). In the anniversary report to the club of Rome: "Come on!" the basis of "new Enlightenment" becomes the search for wisdom4. Apparently, it is about the information revolution. But contemporary networking technologies give an opportunity to quickly obtain any basic information, except that with a complete secrecy level, namely: 1) all the latest technological developments; 2) arrangements of the "mighty of this world" 3) historical sites and studies that do not fit the most recognized humanitarian paradigms. Here we face two forms of motivation for such prohibitions. First, it is copyright and patenting inventions. It is clear that for today this is an issue for big business and, in principle, this approach is fair, given the costly nature of high-tech industries. Second, this is a category of knowledge that immediately gives catastrophic preferences to their owners over other countries and parts of the world. That is the case when "money does not matter".

Accordingly, a large number of current popular science papers, television broadcasts, and information explosions on social networks are devoted to the topics of extraterrestrial interference, reflections on their intellectual and technological level of development. There are constant accusations against the governments of some developed countries about a conspiracy, certain agreements, and cooperation. But official access to this information is closed, which gives rise to a great number of speculations and rumors. The main interest of "aliens" is our vitality and energy. It might actually be more valuable than all the technologies of the planet Earth, and our blood and flesh are "gold" and "diamonds" of the Universe. And this is where arises a phrase regarding Christ's penultimate earthly truth: "He knew!"5. It is clear that today such a statement can be perceived with slight irony, but maybe we still do not know the true value for ourselves. Why does "someone" here decide that there "they" are higher than us in terms of intelligence and technology?

So who then plays the dice? The web is woven. When we decide to create, for example, space forces or colonize the Martian space, we must be aware of new risks, material costs and top managers' calculations that require a modern rational approach to large-scale projects. We have a situation conventionally formulated by Steve Jobs that he would trade all of his technology for one afternoon with Socrates.

\section{Reading Bertrand Russell and others ...}

A classic example of understanding wisdom for me is B. Russell's historical study of western philosophy: "Is there anything we can call wisdom, or what we think is just

4 Weizsäcker, Wijkman, "Come On!”

5 "The New Testament of Our Lord and Saviour Jesus Christ." 
plain madness?"6. Philosophy in his understanding is a "neutral territory" that fills the space between science and religion. Accordingly, philosophy as such cannot be defined, therefore it is doomed to deter attacks and listen to claims from both sides, both science and religion. But retrospectively, in available possibilities, A. Comte first analyzes the history of philosophy, science, religion, and offers such definition: 1) the theological stage as the beginning of the human mind phenomenon formation; 2) the positive stage, that is, a steady and final formation of mental activity 3) the metaphysical stage which is only a transitional form between the first and the third. ${ }^{7} \mathrm{~A}$. Comte calls philosophy precisely metaphysics and B. Russell draws attention to his views to a certain extent. Positivism from the beginning proclaims the philosophy as a "passed" phase in human development. It was predicted that in future metaphysical approach would be replaced by a system of scientific research, which would be able to establish universal laws of the Universe, consciously or unconsciously implemented by humanity. The history of the search for universal laws of the Universe is a detective story, in which we are also included, but this is a topic for separate research.

Thus, positivism ideology creates its philosophy based on rational experimental and practical worldview, and J.S.Mill's idea of Universal Logic of science becomes an important addition. He recognizes mathematical logic as an intellectual model, and thus practically denies the scientific right for the existence of other forms of logic, which considered the functioning of worldview and worldbuilding archetypes as factors of influence on the processes of thinking.

A set of ideas on a given topic in the philosophy of many world public opinion representatives can be offered, but intentionally I want to give an example of such logic in G. Skovoroda's doctrine of the second half of the 18th century. He proclaims the credo: the philosopher carries the people's right "inside of him". Here he brings to the level of theoretical expressiveness an autochthonous approach to the world and a human. The world is a dwelling surrounded by eternity and infinity and contains material-physical dimension, spiritual (or information and cognitive communication), and symbolic world, in which symbols are represented not only by visible signs of being but are images of infinity, and they are created by humans to distinguish between the visible and the invisible. Moreover, physical and spiritual worlds are mediated and united in a symbolic world, where each symbol is a sign of things and is a specific thing that has its meaning. The main point in this logic is that human is involved in all three worlds, and cognition is presented as a creative act that elevates from the "darkness" to the "light" unknown and invisible Being. At the same time, environmental awareness testifies the natural abilities of a human and therefore includes self-learning. Only by following the rule "Know Yourself!" a human can properly understand the world, because its "resurrection", according to Skovoroda, goes only through a human.

In my opinion, when it comes to scientific rationality, it is very important to emphasize on "Kafka Effect", concerning the philosophy of existentialism, which was described by the writer in the novel "The Castle". In particular, the more one seeks to

6 Russell, "The Wisdom of the West", 30.

7 Comte, "The Course of Positive Philosophy." 
achieve his/her goal, based on the logic of knowledge, the more he/she moves away from it. As we see scientific truth is contrasted with existential truth, it embodies the process of experiencing and comprehending life "within" life itself, but the truth cannot be found from the point of view of existential philosophy because it is inseparable from human existence.

While working on this problem according to the views of these thinkers and "reading everything", I have studied a lot of sources from the Old Testament and "Pistis Sopfia" to the works of A. Azimov, B. Alberts, F. Crick, R. Feynman, S. Hawking, and many other scholars and fiction writers.

Concerning keyword terminology, I have paid special attention to Vira Dodonova's work, a well-known Ukrainian researcher on the topic of social rationality. In her monograph, she structurally unfolds the historical dynamics of this concept formation through linguistic and semantic analysis and the system of criteria and methods for its definition. She highlights post-classical problems of the unity of reason and considers wisdom as a modern mode of rationality. The attempt is very successful and complies with the rules and regulations of modern paradigm knowledge. She notes: "The post-nonclassical appeal to the experience of the modern science of philosophical schools and directions long time ago overcome by the modern science as it might seem, testifies, first of all the inability of the mind forms to solve the complex problems which face humanity, and secondly, the great heuristic potential, accumulated by the religious and philosophical systems of the past. The rehabilitation of the classics, the return to tradition, the integration of the achievements of scientific and beyond-scientific knowledge are quite typical for post-nonclassical rationality". ${ }^{8}$ On the contrary, I regard social rationality as a mode of wisdom, but it is "a matter of taste" in our case.

Referring to the post-nonclassical discourse of social rationality, I would like to give an example of a modern legitimization procedure of interpretation theory in the cultural markets of France and the United States. On the basis of tables and graphs, its author Michel Lamont analyzes the intellectual dissemination of J. Derrida's works in the literary markets of France and the United States and provides detailed comments on social, political and institutional factors contributing to such popularity. In his view, "the exalted rhetorical style... cannot be the determining criterion for intellectual legitimation, and testify that every rhetorician in France automatically becomes a philosopher. Much more important is a theoretical brand creation that fits into such an intellectual tradition" (Bourdieu 1986, p. 159). Derrida creates a theoretical apparatus that is unlike any previous philosophical system. Deconstruction contains a set of "no concepts" ... And behind each of them, certain phenomena that are studied. Derrida's theoretical apparatus is a good tool that is always marked by his thought; it can be used as it is in conversation in an intellectual environment". ${ }^{9}$ As a result, it can be argued that we are much less quoting and using J. Derrida's texts, for example, unlike those of Aristotle or I. Kant, but the inability to use a huge layer of terms of interpretation theory is a professional failure.

8 Dodonova, "Post-nonclassical Discourse on Social Rationality", 287.

9 Lamont, "How to become the most important French philosopher", 11-12. 
Returning to T. Kuhn's work, I would like to point out that he defined the scientific paradigm as a "mode of activity of the scientific community". Since each paradigm in different historical conditions formes its so-called standards of research, a new format of communication methods within a scientific environment and the communication of intellectuals with the knowledge society, which consumes them becomes a very important issue. The phenomenon of social reason has always been and still is the key to vital activity of society. The beginning of this phenomenon and its existence form depends solely on the hypothetical suggestions of particular theory representatives. Thereby, it is possible to rely on the assumptions of evolutionary theory, and it can be assumed that the lapse from virtue also provides an opportunity to form social relations, though not protected, but complicated and different!

Thus, the phenomenon of collective wisdom is formed due to the principles and methods of systemic cognition. This human activity aims to master the unknown in the world through the process of assimilating new information and knowledge. The process of cognition itself is always creative and cannot be reduced to scientific cognition, although it allows surviving and arranging own life for all representatives of the genus Homo sapiens. And most importantly, the more comfortable will be our life in this world, the more we will be confused by the question of longevity and Eternity. These are, first and foremost, problems of scientific search.

\section{Cognitive appropriation as personal myth-making}

In a contemporary information environment, when almost everyone is able not only to read and write but also has an opportunity to demonstrate to the whole world oneself, personal impressions and sometimes thoughts about any events happening in it, the process of simulating reality becomes an advantage. Moreover, the objectivity of post-industrial society gets numerous sign-simulative forms that function in accordance with the logic of symbols and financial-mathematical structures and operations. They are formed around a specific code or algorithm for interpreting reality. Moreover, the main, fundamental or first knowledge about objects cannot be distinguished from duplicating and copying because of seriality dominance in the information exchange ${ }^{10}$. So, unprecedented forms of intellectual consumption of collective knowledge are being formed today. Providing a person with vital stability and the possibility of awareness of his/her belonging to the relevant generic origins is positive in the process of knowledge appropriation. In this case, cognitive appropriation turns into a personal myth-making that revolves around its own system of illusions which actually direct life.

Thus, there is an effect of a unique combination of not only the logical and rational cognitive human abilities, but ones are also required to show creative and willful efforts on the basis of emotional and sensual mood. In its turn, such a "mood" is created in the conditions of a certain socio-cultural environment, considering the linguistic and symbolic perception of reality. "All spheres of knowledge border the unknown space around us. When a person enters into the boundary or goes beyond it, he or she

10 Shevchenko, "Friendship with wisdom or the key problems of Ukrainian philosophy", 183. 
comes from science into the sphere of reasoning. His/her speculative activity is also a type of research, and this is, among other things, a philosophy", - says B. Russell. ${ }^{11}$

In the contemporary post-nonclassical scientific period, it has been recognized that the objectivity of any laws can be confirmed only in a particular coordinate system. U. Eco writes: "Even that we deal with a world absolutely surreal where donkeys can fly and princesses come to life with a kiss. But with all the variability and irrationality of this world, the laws that were set at the very beginning of it should be obeyed. So it is necessary to clearly see whether this world is the same ..." 12. But all these worlds are invented only by a man, and he/she becomes assured of his/her knowledge of their existence only if at least one other man agrees with him/her. All people are philosophers for one reason only because we all know the word "death". This is the only knowledge that compels us to form our attitude to life and to move along the paths of our destiny. The proved possibility of immortality in any form will create conditions for the emergence of "not our" wise philosophy. Today, the most well-known are theories, which I conventionally combined into two peculiar propositions. The first is represented by a metaphorical form of satirical notion of bodily resurrection when all life is frozen, nothing changes, does not get spoilt and is not born, so that the Eternity is a pointless and rather boring plaything. Moreover, as R. Feynman noted, "To die the second time would be terribly boring" ${ }^{13}$. The second one includes several options to execute, when the biblical idea of resurrection in the conditions of revolutionary achievements in molecular biology, it does not seem so unrealizable.

So, if we can finally find out the cause and the way of our origin, formulate the universal principles of Universe existence, and then the rational order of Borges' Library of Babel loses its meaning. It is here that we unfold the limitless possibilities of our myth-making. The philosophical way of thinking provides an opportunity to satisfy everyone's desire to know and understand the principles of existence of our world in an infinite space in terms of eternity.

Contemporary empirical science has provided a practical opportunity to observe the appearance and prenatal development of a baby, and any ultrasound doctor or a person who has repeatedly observed embryos formation will argue that all of them practically from 3 to 5 months have their own characteristic behavior.

Moreover, today we can hear the sound of the human genome. For me, this is a whisper of prayers, which execution we call then the creation of nature or "from birth". Even Cicero wrote that children are very quickly mastering a large number of complex actions and objects and it seems that they are not learning all this for the first time, but just remembering. For example, in the middle of the last century in the works of $E$. Toffler emerged the concept of futuristic shock, which became widespread in various fields of public opinion. But now, looking at my children and grandchildren, as well as the children of my friends, I do not see a clear futurological shock on their part. Today children seem to be born with gadgets, and we perceive a lot of things from

11 Russell, "Wisdom of the West", 28.

12 Eco, "The Name of the Rose."

13 "Richard Feynman. The most versatile theoretical physicist." 
a very practical point of view (Here is a small explanation: we are talking about our "ordinary" smarties and beauties, not those children about who ufologists, contractors, etc., tell us. Though in our opinion, first of all, we should listen to the opinions of educators and psychologists who deal with such children). We pay attention to the significant changes in the system of relations that are formed between the process of knowledge accumulation and their realization in the material carriers of production. Modern technologies do not create goods themselves; they reproduce biological and social life forms. That is, the process of dematerialization does not take place; on the contrary, the new technological stage is characterized by the reification of life and its production. The process of blurring the boundaries between science and society, science and politics are accelerating, i.e., the essence of scientific practice today is closely linked to the relations of production and the existing internal conflicts.

When I read and write that modern technology is biotechnological in nature that there are peculiar hybrid forms of combining biotechnology with informational technology, genetic with communication technology, "cybernetic organism" contains organic and technical qualities, which separates the question of their proportionality, then the story of formation of the very concept of philosophy in ancient times comes to mind, because then all knowledge would be philosophy.

Modern technological forms are a consistent process of forming the actual mode of human action, and the main moment of the cognition process is the study of ways and methods of creating artificial objects, systems, worlds. So, today we turn to such a "mainstream of modern philosophy that began when Kant exchanged the structure of the world for the structure of the mind, continued when C. I. Lewis exchanged the structure of the mind for the structure of concepts, and that now proceeds to exchange the structure of concepts for the structure of several symbol systems of science, philosophy, the arts, perception, and everyday discourse. The movement is from unique truth and a world fixed and found to a diversity of right and even conflicting versions or worlds in the making." 14

Thus, the desire of certain scientific circles representatives (such as W. Jameson, J. Dewey, M. Lipman, etc.) to bring up critical thinking to people is absolutely noble. But today our number is about seven billion, so it is simply impossible. The point is that both previous theological and contemporary hypotheses of understanding the universe have the character of myth-making. One way or another, we believe in them, but we live and work here and now: "Reality is more important than PR: nature is not to be fooled" 15 , - says the famous American physicist Richard Feynman.

\section{About the criteria for collective wisdom}

In contemporary philosophical thought, the existence of wisdom is not only differently understood, but sometimes simply denied as an object of thinking and analysis. But by what other notion can be defined as the process of combining acquired life experience and perceived knowledge of it? How can be defined as the process of providing a practical opportunity to survive and unmistakably act in different dimen-

14 Goodman, "Ways of worldmaking”, 4.

15 "Richard Feynman. The most versatile theoretical physicist." 
sions of the world? This process is difficult to define other than wisdom, "love for wisdom" or sophiology. The research experience of the search for the "objective" criterion for wisdom can offer only a mosaic game of historical and philosophical views since the understanding of this category must take into account the diverse social and historical practices and all worldview polyphony of understanding of the essence and place of a human in the world. To go on with the discussion, we will try to offer our understanding of the collective wisdom of the contemporary intellectual world and to formulate some of its criteria.

Undoubtedly, the first sign of wisdom is human will manifestation, one's belief in the possibility of cognition the world's existence and the value of personal presence here and now in this world. But in order to understand the "rules of motion" of one's will and knowledge, the presence of the law, the first criterion, is necessary. The best explanation of this criterion is Kant's statement: "Man only expects from Providence the education of the human species in its entirety, that is, collectively (universorum), and not individually (singulorum), where the multitude does not represent a system, but merely an aggregate collected at random. He only expects from Providence that he be guided toward a civil constitution based on the principles of freedom, but at the same time he expects that this constitution be based on a coercive principle of statuatory quality". ${ }^{16}$ Such a specific feature of the law, as the ability to maintain stability under certain circumstances, gives a human faith in one's own strength and a relative possibility to navigate confidentially in this complicated social and natural world. The law is a well-known rational measure of human interaction, and it also shapes an understandable world of interdependencies between the things of nature. Let us illustrate this approach with a B. Alberts' quote from a basic textbook on molecular biology: "But, perhaps, even more, striking is the masterful composition of the mechanisms that we encounter. The deeper we get into the cell, the more we realize how much we have yet to learn" ${ }^{17}$. That is, in the period of rapid scientific revolutions in different fields, we again return to the classical thesis - the more we know, the more we do not know. However, the process of cognition is the only way leading to the growth of our wisdom.

Accordingly, the second criterion is knowledge as an experience of social rationality. Definitely, knowledge is information about the world, causes, and principles of the existence of things and environmental phenomena, their content, and properties. For example, for M. Foucault, knowledge cannot be neutral or objective because it is always a "product of one's own relations." He believes that in contemporary society there is a struggle for the "power of interpretation" of different ideological systems. ${ }^{18}$ Dominant ideologies define an industrial culture (mass media) that, accordingly, imposes on individuals their own language, and the identification of thinking with language forms a way of thinking.

Thus, dominant ideologies limit the ability of individuals to understand their life experience, "material being", and therefore language is no longer just a means 16 Kant, "Anthropology from a pragmatic point of view", 256.

17 Alberts, "Molecular biology of the cell", 5.

18 Foucault, "The Order of Things: An Archaeology of the Human Sciences". 
of cognition, but also a tool for social communication. Another option is possible, in particular, according to S. Krymskyi, "the aggregative understanding of "unity", the summation of individual efforts in the collective is supplemented by the principle of monadicism - the embodiment and representation of the collective in the individual". ${ }^{19}$ Therefore, the third criterion for collective wisdom is a tradition as the unity of scientific experience.

I have already outlined the principles of scientific imitation in the process of forming a system of paradigm knowledge, and have paid attention to changes in the post-nonclassical approach to scientific methodology, but the notion of tradition must take into account the significance of the established, historically and genetically determined order of the Universe of people. The specificity of traditions is that they entirely "produce a human", taking into account certain features of national culture. Initially, tradition has the forms of individual assimilation of symbols, meanings, and norms, rules of action, experience and knowledge produced by a particular people in communication with parents. The assimilation of symbols and norms characterizes the normal existence of a person in this culture. ... Life path is made on one's own, and tradition, as a connection with society and the natural environment, is a matter of life and death for man. ${ }^{20}$ The same applies to a survival question of a particular nation and humanity on the principles and basis of scientific knowledge development.

The next criterion is personal values and beliefs, where values act as symbols and ideas that express and condition a worldview, within which actions, tools, and things make sense, are understood and interpreted by people. Values allow a person to evaluate his or her experience and knowledge, but wisdom is manifested in an activity-based attitude that is based on belief. Beliefs practically guide a person's will to act, they directly rely on the belief in truth and justice of the law. The results of manifesting a human being are not only material and production indicators of the effectiveness of people life activity in a certain historical period, but also those signs or symbols that have different character manifestation in intellectual discourse or exist in the form of a conceptual apparatus specific to a particular discipline. Philosophical texts of a particular historical age may serve as an example of such an approach. Intellectual achievements in the field of social knowledge are fixed in them. The individual worldview of a thinker creates a special intellectual discourse. A synthesis between ideas about the material structure of social being and possible ways of manifesting its existence in real vital time-space is made in it.

Love, as a sign of ontological optimism, is certainly a mandatory criterion for collective wisdom. And the religious significance of the apocatastasis outweighs the fear of the apocalyptic development of world events. We love traveling the world and we are constantly looking for adventure, both literally and figuratively, just because we love the world just like that. Our love is a free communication of people who seek to know the meaning of life. Love provides interaction or mixing of various processes, whereby the world exists as a whole.

19 Crimean, "Under the signature of Sofia", 275.

20 Shevchenko, "Friendship with wisdom or key problems of Ukrainian philosophy", 192. 
Thus, collective wisdom is an integral indicator and determinant of social progress and transformation mechanism. We constantly use other people's intelligence, and this process is growing in scale, but communication methods between intellectual proposals do not possess modern forms and confirmation of objectivity of certain knowledge takes a lot of time. Such proposed criteria for collective wisdom as law as a known rational measure, knowledge as an experience of social reason, tradition as a unity of scientific experience, personal values, and beliefs, as well as love as an ontological optimism of our existence can in some ways help to form a unified platform for intellectual communication.

Finding ideas and dialogue together as intellectual beams of the great Milky Way

A good philosopher is a writer. And then raises a problem of the objectivity of his/ her research and their perception in a scientific environment. The fact is that no one can be together because of a "creative misunderstanding" and a massive distortion of proven facts by fantasies and myths created by contemporary means of communication. As a result of recent scientific achievements, as in the ancient circles of "knowledge - ignorance", we face a chasm of new research problems.

It would like to note that today there is no reason to create a new philosophy ${ }^{21}$, because we still have not practically resolved a single issue posed by the "old" philosophy. However, the principle harmonization of scientific postulates with the creative possibilities of mastering modern problems through philosophical methodology can be considered as a process of wisdom growth. The intertwining of archetypes of world-building and life-building, as well as the close interaction of philosophy with both science and religion, making it a complex, diverse and contradictory sphere of knowledge. It should be considered that the form and content, formulation and ways of solving ideological problems are changing under the general identity of the dominant archetypes of a particular national philosophy. The complex of these contradictions can be rethought due to new "forms" of dialogue, and the new rationality appears in the form of communicative discourse ${ }^{22}$ as overcoming the instrumental mind. In this case, we are talking about new forms of argumentative dialogue, thus the previous problematic nature of critical theory acquires a significance of productive scientific research.

So our philosophy of the Universe is ourselves. Certainly, no one cancels genius. But the current volume of knowledge requires joining efforts and thought consensus through new ways of communication and social interaction between people of the scientific professional sphere, first of all. All this is required in order to later not to think about the degree of our guilt in accordance with A. Einstein's life example. ${ }^{23}$ The risks posed by the process of widening ignorance gulf must be overcome by the holography of intellectual communication as a basis of collective wisdom. Certainly, this is a metaphorical name, but we are impressed by the translation of the term "holography" (ancient Greek ǒ $\lambda$ ऽ - full + $\gamma \rho \alpha ́ \alpha \omega$ - write) as a set of technologies for accurate recording, reproduction and reformatting the reality image, without bots, information noise, etc.

21 Weizsäcker, Wijkman, "Come On!"

22 Habermas, "Rationality and Democracy", 110.

23 Wikipedia. "Einstein-Szilárd letter". 
In addition, I propose new methods for registration of "intellectual rays", which should take into account the results of contemporary research methodology of quantum theory, molecular biology and other revolutionary opportunities in various fields of knowledge. This is precisely the problem that will be presented in further reasoning.

P.S. In concluding the essay, I want to return to Hemingway's perception of the world: "Up the road, in his shack, the old man was sleeping again. He was still sleeping on his face and the boy was sitting by him watching him. The old man was dreaming about the lions." ${ }^{24}$ So, God does not really play dice, he just knows how to play with the worlds and with us.

\section{References}

Alberts, B., et. al. Molecular biology of the cell. Izhevsk: Research Center "Regular and Chaotic Dynamics", Institute for Computer Research, 2012.

The New Testament of Our Lord and Saviour Jesus Christ: Translated Out of the Original Greek: And With the Former Translations Diligently Compared And Revised, By His Majestys Special Command. Salt Lake City: The Church of Jesus Christ of Latter-day Saints, 2013.

Comte, A. The Course of Positive Philosophy. 1844. http://comte.newgod.su/lib/duh-pozitivnoj-filosofii.

Dodonova, V. I. Post-non-classical Discourse on Social Rationality. Donetsk: DonNU Publishing House, 2011.

Foucault, M. The Order of Things: An Archaeology of the Human Sciences. Moscow: Progress, 1977.

Goodman, H. N. Ways of worldmaking. The Harvester Press, 1978.

Habermas, J. Rationality and Democracy. Moscow: Academia, 1995.

Hemingway. E. The old man and the sea. Odessa: "Mayak" Publishing House, 1977.

Kant, I. Anthropology from a pragmatic point of view. Translated by Victor Lyle Dowdell Revised and Edited by Hans H. Rudnick. Southern Illinois University Press, 1996.

Krymskyi, S. B. Under the signature of Sofia. Kyiv: Kyiv-Mohyla Academy, 2008.

Kuhn, T. The structure of scientific revolutions. Kyiv: Port-Royal, 2001.

Lamont, M. How to become the most important French philosopher: the case of Derrida. Logos, 4-5 (72) (2009): 3-42.

Russell, B. Wisdom of the West: a historical survey of Western philosophy in its social and political setting. Edited by P. Fulkes; V. A. Malinina. Moscow: Respublika, 1998.

Shevchenko, V. I. Friendship with wisdom or the key problems of Ukrainian philosophy (Theoretical and methodological commentary on the course of philosophy in higher educational esteblishments). Moscow: Printing Center "Folio", 2007.

Eco, U. Marginal notes on "The Name of the Rose". St. Petersburg: "Symposium", 2005.

Weizsäcker, E. U. von, Wijkman, A. Come On! Capitalism, Short-termism, Population and the Destruction of the Planet: A Report to the Club of Rome. Springer Science+Business Media LLC, 2018.

Richard Feynman. The most versatile theoretical physicist. + selection of literature. LIBPSTU, January 17, 2018. https://libpstu.wordpress.com/2018/01/17/ричард-фейнмансамый-разносторонний/.

Wikipedia. "James Watson.” https://en.wikipedia.org/wiki/James_Watson.

Wikipedia. "Einstein-Szilárd letter." https://en.wikipedia.org/wiki/Einstein-Szilárd_letter.

24 Hemingway, "The old man and the sea", 81. 